Winter 2008

\title{
From Agitation to Institutionalization: The Student Anti- Sweatshop Movement in the New Millennium
}

Purnima Bose

Indiana University

Follow this and additional works at: https://www.repository.law.indiana.edu/ijgls

Part of the Civil Law Commons, and the International Law Commons

\section{Recommended Citation}

Bose, Purnima (2008) "From Agitation to Institutionalization: The Student Anti-Sweatshop Movement in the New Millennium," Indiana Journal of Global Legal Studies: Vol. 15 : Iss. 1 , Article 9.

Available at: https://www.repository.law.indiana.edu/ijgls/vol15/iss1/9

This Symposium is brought to you for free and open access by the Law School Journals at Digital Repository @ Maurer Law. It has been accepted for inclusion in Indiana Journal of Global Legal Studies by an authorized editor of Digital Repository @ Maurer Law. For more information, please contact rvaughan@indiana.edu.

\section{$\Psi$}

JEROME HALL LAW LIBRARY

INDIANA UNIVERSITY

Maurer School of Law
Blooming ton 


\title{
From Agitation to Institutionalization: The Student Anti-Sweatshop Movement in the New Millennium
}

\author{
Purnima Bose*
}

\begin{abstract}
This article provides an overview of the student anti-sweatshop movement and argues that the movement has been somewhat successful at changing policies. The primary objectives are twofold: first, to supplement existing literature on the anti-sweatshop movement by offering an account of its emergence and evolution at Indiana University - Bloomington; and second, to describe the Designated Suppliers Program (DSP), a United Students Against Sweatshops (USAS) initiative that proactively seeks to improve conditions for workers producing university-licensed apparel.
\end{abstract}

\section{INTRODUCTION}

Stuart Hall has stressed the importance of institutionalization as a necessary step in the road to paving collective intellectual projects. ${ }^{1}$ Yet it is precisely this phase that presents a road block to social movements that have been driven primarily by activities centered on protest against existing institutions instead of the creation of new ones. A decade after its emergence, the university-based antisweatshop movement has managed to steer clear of such obstacles by establishing several alternative institutions such as United Students Against Sweatshops

* Associate Professor, English Department, Indiana University-Bloomington. This article had its origins as an invited talk for the International Cultural Studies Certificate Program at the University of Hawai'i; I subsequently presented a shorter version of the talk at Indiana University-Bloomington for the "Democracy and the Transnational Private Sector" Symposium. I am grateful to the audiences in both locations for their insightful comments and questions. In addition, Jeremy Blasi, Megan Hise, Laura E. Lyons, Ursula McTaggart, and Nancy Steffan graciously offered valuable suggestions and commentary, and I thank them. All errors, of course, are mine.

1. Lawrence Grossberg, On Postmodernism and Articulation: An Interview with Stuart Hall, in Stuart Hall: Critical Dialogues in Cultural Studies 131, 149 (David Morley \& Kuan-Hsing Chen eds., 1996).

Indiana Journal of Global Legal Studies Vol. 15\#1 (Winter 2008)

CIndiana University School of Law 
(USAS) and the Worker Rights Consortium (WRC) that have achieved measured success in improving the lives of some garment workers. Rather than attend to these dynamic institutions, however, many accounts of the movement have latched on to questions of identity politics, reductively positioning student activists as naive and as having little understanding of the complexities of the global economy. The dynamic responses of student activists to structural challenges posed by the apparel industry and the global economy suggest that the focus on identity is misplaced. In this article, my aims are twofold: first, to supplement existing literature on the anti-sweatshop movement by offering an account of its emergence and evolution at a midwestern institution, Indiana University-Bloomington; and second, to describe the Designated Suppliers Program (DSP), a USAS initiative that proactively seeks to improve conditions for workers producing universitylicensed apparel. ${ }^{2}$ The Indiana student group No Sweat!'s early emphasis on education and mobilization of different constituencies (students, faculty, and the Bloomington community) might prove a useful model for similar organizing attempts at other institutions. An investigation of the DSP reveals the ways in which the student anti-sweatshop movement has made the transition from agitation to institutionalization-from the confrontational politics of spectacle to the discur-

2. The literature on sweatshops is fairly voluminous, see generally EDNa Bonacich \& Richard P. Applebaum, Behind the Label: Inequality In the Los Angeles Apparel Industry (2000), Barbara Ehrenreich \& Annette Fuentes, Women In the Global Factory (1983) (detailing the various conditions of women in the global economy); Cynthia Enloe, Bananas, Beaches and Bases: Making Sense of Feminist Politics (1989) (giving a nontraditional analysis of globalization which reveals the critical role of women in politics today); Miriam Ching Yoon Louie, Sweatshop Warriors: Immigrant Women Workers Take on the Global Factory (2001) (showcasing interviews of immigrant women workers in the United States who vocalize their concerns amidst opposition and fight to assert their rights). For accounts of the student anti-sweatshop movement in the United States, see Liza Featherstone \& United Students Against Sweatshops, Students Against Sweatshops (2002) (detailing the anti-sweatshop movement that has reached hundreds of American college campuses in the past three years); Barbara Foley, Looking Backward, 2002-1969: Campus Activism in the Era of Globalization, in World Bank Literature (Amitava Kumar ed., 2003) (detailing the substandard conditions found in sweatshops located in Sub-Saharan Africa and most of Latin America); Jeffrey C. Isaac, Thinking About the Antisweatshop Movement, in Dissenr 100 (Fall 2001) (evaluating the anti-sweatshop movement in terms of its reformist impulses), and NAOMI Klein, No Logo (2000) (describing new forms of activism against corporate forms of globalization).

The anti-sweatshop movement in the United States, of course, consists of a network of organizations such as Press for Change, Global Exchange, the National Labor Committee, Sweatshop Watch, and others, along with trade unions such as UNITE. In addition, nonprofit, directmarketing, fair-trade organizations, such as Marketplace, are creating alternative forms of production. My focus in this article, however, is on the student movement. 
sive politics of negotiations and contracts--a transition that could potentially alter the production of university-licensed garments.

Before describing the genesis of the national anti-sweatshop student movement and its manifestation at Indiana University, I consider four recurrent themes, and their shortcomings, that dominate contemporary discussions of sweatshops and industrialization, along with common misconceptions of the student antisweatshop movement. I follow this discussion with an account of the national and local anti-sweatshop student movements. The subsequent elaboration of the DSP recognizes student activists as astute theorists of the global economy by addressing their assessment of structural impediments to meaningful change within the garment industry. A section on terms such as "freedom of association" and the "living wage" which follows, underscores USAS's and the DSP Working Group's nuanced and thoughtful responses to the challenges of devising definitions that are flexible enough to accommodate different national contexts. Finally, I conclude with some preliminary observations on the tangible and intangible benefits of the anti-sweatshop movement for garment workers and student activists.

Writing an account of this kind necessarily entails examining and reflecting on "ephemera," a broad range of materials such as newspaper articles, leaflets, posters, e-mail communications, and minutes from meetings, which, according to Laura E. Lyons, are forms of writing and visualizations that are "markedly oc-

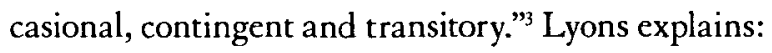

In contrast to the sometimes monumental quality of traditional literary genres that withstand the 'test of time,' or the sense of a 'lasting legacy' that imbues certain forms of autobiography, a relatively short shelf-life fixes the limits of ephemera, the importance of which can be, quite literally, 'for a day.' Consequently, ephemera offer a less apparent record of the intellectual and political shifts and developments within a movement... . Rather than the heroic narrative that can be written after objectives have been achieved or the elegiac narrative produced in response to heavy losses, ephemera concern the dailiness of struggle. ${ }^{4}$

3. Laura E. Lyons, Hand-to-Hand History: Ephemera and Irish Republicanism, 5 InTERvenrions 407,410 (2003).

4. Id. 
The contingent and transitory nature of such writing illuminates intellectual developments, ideological shifts, and tactical changes that shed light on how organizations respond to the challenges and crises inevitably confronted in the process of institutionalization. Because they are written in the middle of things, before the outcome of decisions, actions, and protests are evident, ephemera give us snapshots of movements; images that can blur, fade, or come more acutely into focus with the passage of time. For institutions such as the WRC that value transparency, some important ephemera, including correspondence with legal counsel and minutes of board meetings, are available on its website. USAS also relies on its website to disseminate templates for posters and flyers to aid student campaigns.

The anti-sweatshop movement itself is part of a much larger movement against corporate globalization and neoliberal economic policies that gained visibility following the Seattle protests during the World Trade Organization talks in 1999. Reacting to policies associated with the neoliberal agenda of promoting the rule of the market, reducing public expenditure for social services, and advocating deregulation and privatization, activists have become increasingly disillusioned by the state's inability and unwillingness to regulate corporations. Henry Giroux has remarked on the ways in which neoliberalism codes all problems as private rather than social in nature, transforming profit making into the essence of democracy and figuring the paradigmatic citizen as the consumer. ${ }^{6}$ Against such figurations, student activists and their allies are part of a transnational private sector that is attempting to empower garment workers by formulating policies that address the nexus of international commerce and human rights. Their successes and failures have obvious relevance for those concerned with strengthening democracy in the United States and abroad, which cannot flourish without a global redistribution of the wealth generated by neoliberalism. The DSP represents a modest but concrete step in this direction.

5. In October 1999, approximately fifty thousand people demonstrated against the World Trade Organization's ministerial meeting in Seattle, Washington. The WTO hoped to launch a millennial round of trade negotiations, but confronted trade unionists, environmentalists, human rights advocates, anarchists, and others who opposed the new global economy. See Alexander Cockburn et al., Five Days that Shook the World: Seattle and Beyond (2000).

6. Henry A. Giroux, The Terror of Neoliberalism: Rethinking the Significance of Cultural Poliitics, 32 C. Literature 1,8-9 (Winter 2005). 


\section{The Four Shortcomings of "the Sweatshop-Progress Metanarrative:" Exploited Labor and Industrial Modernity}

Almost all apparel in the global economy is produced under conditions that most decent people would find horrifying. The generally sixteen to twenty-twoyear-old women workers who comprise the labor force receive substandard wages, face arbitrary punishment, risk contracting occupational-related health conditions, and are denied the right of association. In addition, they are subject to gender-specific rights violations in the name of increased productivity such as Depo-Provera injections to halt their menstrual cycles and the administering of routine pregnancy tests. ${ }^{7}$ In spite of these conditions, however, criticism of the anti-sweatshop movement voiced by mainstream economists and political scientists relies on a metanarrative identified by Judi Nitsch as the "sweatshop-progress metanarrative" which identifies sweatshop labor as a "point of progress" for industrialization and the empowerment of workers. ${ }^{8}$ Drawing on the history of the industrial revolution in Britain and the United States, the underlying assumption of this metanarrative is that Third World countries must pass through sweatshop modes of production before they can enter into First World industrial modernity. The development of a robust British and North American industrial base in which workers now apparently enjoy high salaries, health benefits, and occupational safety protection, according to the sweatshop-progress metanarrative, is the inevitable outcome of sweatshop labor in the nineteenth and early twentieth centuries.

The sweatshop-progress metanarrative has also absorbed the binary views and Orientalist tropes associated with colonial discourse in its construction of the Third World as the natural setting for sweatshop labor, a construction that "places the shop just beyond the space of contemporary Western labor conditions and public policy." Nitsch eloquently summarizes the assumptions underwriting this view:

7. Depo-Provera is a form of contraception, which has worrisome side effects including the risk of considerable bone loss. Adolescence is a crucial period for bone development and the administration of Depo-Provera injections can lead to osteoporosis later in life. Garment workers, many of whom are adolescents, might experience the long term degradation of their health as a result of these injections. Pfizer, Physician Information: Depo-Provera Contraceptive Injection (Nov. 2004), http://www.pfizer.com/pfizer/download/uspi_depo_provera_contraceptive.pdf.

8. Judi Nitsch, (Inter) Nationalism: Narrative Global Social Justice and Anti-Colonial Nationalisms 8 (unpublished dissertation, Indiana University-Bloomington) (on file with author).

9. Id. at 12 . 
The sweatshop-progress metanarrative then creates the Third World as the space of continual economic poverty, populated with standard characters and tropes of global poverty: corrupt politicians, browbeaten workers, oppressed women, emaciated children, dilapidated huts, squalid factories. Not simply a replication of the 19th century Anglo-American tenement shop, the 'new' Third World sweatshop narrative draws on pre-existing formations of a monolithic Third World caught in the inescapable grasp of economic and environmental disaster, ethnic violence and political chaos. ${ }^{10}$

Sweatshops are naturalized as part of the impoverished landscape of the Third World. Their presence in the industrialized world is explained as an atavistic anomaly despite the Department of Labor's (DOL) estimate that about twothirds of garment manufacturing shops in Los Angeles, which has the highest number of apparel workers in the United States followed by New York, fail to comply with federal minimum wage and overtime laws. ${ }^{11}$ The actual figure could be higher since the DOL survey was conducted in registered factories only. ${ }^{12}$

Trumpeting such flippant and frankly offensive titles as "Two Cheers for Sweatshops," "Sweatshop Chic," and "In Praise of the Maligned Sweatshop," recent journalistic manifestations of the sweatshop-progress metanarrative are based on a selective view of history that elides the role of organized labor and state intervention in improving working conditions and wages. ${ }^{13}$ From an analytic perspective, the shortcomings of the sweatshop-progress narrative are fourfold..$^{14}$ First, the sweat-

10. Id.

11. U.S. Department of Labor, News Release: Only One-Third of Southern California Garment Shops in Compliance with Federal Labor Laws (Aug. 25, 2000), http://www.dol.gov/esa/media/ press/whd/sfwh112.htm.

12. E-mail from Rini Chakraborty, Executive Director of Sweatshop Watch, to Purnima Bose, Associate Professor of English, Indiana University-Bloomington (Aug. 7, 2007, 20:07:07 EST) (on file with author). For additional statistics on the U.S. industry, see Sweatshop Watch, Resources, http://www.sweatshopwatch.org/index.php? s $=50 \& \mathrm{r}=4$ (last visited Jan. 13, 2008).

13. E-mail from (on file with author) Jonah Goldberg, Sweatshop Chic: The Know-Nothings Find a Cause, in NAT'L Rev. Apr. 2, 2001, at 30; Nicholas D. Kristof, In Praise of the Maligned Sweatshop, Op-Ed., The N.Y. Times, June 6, 2006; Nicholas D. Kristof \& Sheryl Wudunn, Two Cheers for Sweatshops, in The N.Y. Times Magazine, Sept. 24, 2000.

14. John Miller identifies and analyzes several other themes in the reactions of mainstream economics to critiques of sweatshops: one, that the enforcement of existing laws will remedy labor abuses; two, that workers "freely choose" these jobs; three, that sweatshops offer higher prevailing wages than other jobs in developing economies. See John Miller, Why Economists Are Wrong About Sweatshops and the Antisweatshop Movement 46 Challenge, Jan.-Feb. 2003, at 93, 99. 
shop is privileged as the site in the Industrial Revolution of technological and industrial innovation to the exclusion of other industries. To be sure, innovations in textile production proved crucial to the start of the Industrial Revolution: the invention of the spinning jenny, flying shuttle, roller spinning machine, and the flyer-and-bobbin system in the eighteenth century dramatically increased the productivity of individual workers while the organization of labor into factories, pioneered by the textile sector, became the model for production more generally. The Industrial Revolution, however, could not have advanced without technological innovations in other industries such as metallurgy, mining, steam power, the large scale production of chemicals, and the manufacturing of machine tools.

Related to the positing of the textile industry as a metonym for the Industrial Revolution, a second shortcoming of the sweatshop-progress narrative is that it implicitly grants the sweatshop a kind of agency that in actuality attaches to garment workers and organized labor. The existence of sweatshops did not in and of itself catapult the British and American economies into the modern era of production. Rather, in the United States, the heroic efforts of many women and men working collectively in organizations such as The International Ladies' Garment Workers' Union and the Amalgamated Clothing Workers of America (which merged in 1995 to form the Union of Needletrades, Industrial, and Textile Employees (UNITE)), the National Textile Workers Union (NTWU), the Industrial Workers of the World (IWW), the Women's Trade Union League (WTUL), along with other groups, fought, sometimes literally, for wage increases and improvements in labor conditions. ${ }^{15}$ Two years before the infamous Triangle Shirtwaist Factory Fire in 1911 about 20 percent of its workforce walked out in protest of labor conditions, leading to the fourteen-week "Uprising of 20,000" among New York's garment workers. This walkout was one of many actions in different locations and decades undertaken by garment and textile workers in the country.

15. For accounts of this history, see generally Philip S. Foner, Women and the American Labor Movement: From Colonial Times to the Eve of World War I (1979) (giving an overview of the impact women had on the labor movement during early American history); ANNELise Orleck, Common Sense and a Little Fire: Women and Working-Class Politics in the United States, 1900-1965 (1995) (detailing the lives of four Jewish immigrant organizers who were active in the working class labor movement); Howard Zinn, A People's History of the United States (Howard Zinn ed., Harper Perennial 1995) (highlighting the role of marginalized groups in making American history). In 2004, UNITE merged with the Hotel Employees and Restaurant Employees to form UNITE HERE. 
In 1934, textile strikes spread throughout the United States as some 421,000 workers rallied, prompting President Roosevelt to establish a board of mediation. ${ }^{16}$

It was arguably the cumulated and concerted efforts of organized labor in strikes such as those in 1909 and 1934 that led to meaningful state intervention in labor rights, the absence of which constitutes the third shortcoming of the sweatshop-progress metanarrative. While its precursor, the 1933 New Deal National Industrial Recovery Act (NIRA), was deemed unconstitutional by the Supreme Court, the Fair Labor Standards Act (FLSA) of 1938, had the strong backing of both the Amalgamated Clothing Workers Union (ACWU) and the International Ladies' Garment Workers' Union (ILGWU). FLSA established a minimum wage, limited the workweek to forty-four hours, set standards for overtime compensation, and banned child labor from interstate commerce. ${ }^{17}$ Periodically amended to keep constant with prevailing labor standards, the safeguards provided to workers through the FLSA underscore the importance of the state's role in guaranteeing fair wages and a healthy work environment, a role that the sweatshop-progress metanarrative elides. In spite of these safeguards, most U.S. workers, except for those at the highest end of the pay spectrum, have experienced a decline in real wages since $2000 .^{18}$

The fourth shortcoming of the sweatshop-progress metanarrative is its characterization of the contemporary United States as a utopian work environment with generous compensation for workers. Since the 1994 North American Free Trade Agreement (NAFTA) welded together three economies at very different levels of development, hundreds of thousands of U.S. workers have lost high-wage manufacturing jobs with benefits. Some sources estimate the figure at three million manufacturing jobs and note that 525,000 U.S. workers have been certified for assistance under the NAFTA-Trade Adjustment Assistance program, only one of several assistance programs in place. ${ }^{19}$ Many of these workers have found new jobs in the service sector, which typically pay 23 to 77 percent less than their previous wages and offer no benefits. ${ }^{20}$ Barbara Ehrenreich's Nickel and Dimed, which chronicles her struggle and those of her coworkers to survive on minimum wage jobs in the food service, janitorial sector, and retail sales, refutes the sweat-

16. ZiNN, supra note 15 , at $387-88$.

17. Jonathan Grossman, Fair Labor Standards Act of 1938: Maximum Struggle for a Minimum Wage, http://www.dol.gov/oasam/programs/history/flsa1938.htm (last visited June 14, 2008).

18. Jared Bernstein, Wage Growth Slows for Most Workers Between 2000 and 2005, Econ. PoL'y Instiт. (Jan. 11, 2006), http://www.epinet.org/content.cfm/webfeatures_snapshots_20060111.

19. Public Citizen, NAFTA at Ten Series: U.S. Workers' Jobs, Wages and Economic Security, http:// www.citizen.org/documents/NAFTA_10_jobs.pdf.

20. Id. 
shop-progress metanarrative's rosy portrayal of North American workers as economically secure. ${ }^{21}$

The sweatshop-progress metanarrative, then, articulates sweatshops, industrial modernity, and economic prosperity without acknowledging the role of organized labor or state intervention in setting the labor and wage standards that have contributed historically to the well being of the U.S. workforce relative to workers in other countries, particularly in the global South. ${ }^{22}$ State intervention can have a major impact in the development of the textile industry in ways that fuel industrialization and economic security for workers as the example of Japan illustrates. In Making Sweatshops: The Globalization of the U.S. Apparel Industry, Ellen Israel Rosen describes how the U.S. military occupation of Japan under General Douglas MacArthur following World War II was charged with the "restructuring of Japan's political system, the democratization of its civil society, and its industrial reconstruction. ${ }^{.33} \mathrm{~A}$ crucial aspect of industrialization entailed developing Japan's textile industry, which was seen as an alternative to developing industries that could be oriented to military needs. While the Japanese government allocated materials, working capital, power, and coal to the textile industry and granted textile workers extra rations of food and clothing, the United States War Department was in charge of production schedules and set the price of inputs, including wages. ${ }^{24}$ The United States managed Japan's efforts to reconstruct the textile industry by supplying it with raw materials such as cotton and helping to seek out markets for the finished products. ${ }^{25}$

Representing a fictional account of industrialization in Britain and the United States, the sweatshop-progress metanarrative could achieve some mimetic legitimacy if it acknowledged organized labor's and the state's vital role in the economy. To make the metanarrative a reality in ways that could benefit workers and galvanize economic development, as the example of Japan suggests, requires the inter-

21. Barbara Ehrenreich, Nickel and Dimed: On (Not) Getting by In America (2001) (detailing the experience of an unskilled worker making minimum wage).

22. The term "global South" is used by academics as shorthand for those countries formerly considered part of the Third World, many of which are in the southern hemisphere. For a discussion of the history of the term and the debates around its usage, see Arif Dirlik, Global South: Predicament and Promise, The Global South, Jan. 2007, at 12.

23. Ellen Isreal Rosen, Making Sweatshops: The Globalization of the U.S. Apparel InDUSTRY 27 (2002).

24. Id. at 29.

25. For the United States, admittedly, support for Japan's textile industry was another weapon in its Cold War foreign policy arsenal: Japan was perceived as the potential "stabilizer" of Asia. Hence, U.S. officials were eager to tie its economy to that of the United States and make it a successful capitalist model for other Asian countries to emulate. Id. at 32 . 
vention of the state and policies that set fair labor standards and wages. Ann Harrison and Jason Scorse's study of Indonesian labor markets found that U.S. government pressure, in combination with anti-sweatshop campaigns, resulted in a 50 percent increase in real wages for Indonesian workers without significant loss of employment in apparel and textile factories. ${ }^{26}$ Given the current global infatuation with free trade and neoliberalism, it is unlikely that governments will take this initiative in the absence of demands advanced by workers and supported by their allies such as students in the anti-sweatshop movement.

\section{Misconceptions of the Imperialist-Activist Metanarrative}

A related metanarrative to the sweatshop-progress metanarrative, the imperialist-activist metanarrative, posits student activists as privileged subjects who misguidedly engage in imperialistic and paternalistic forms of action that perversely, if unintentionally, harm workers in the Third World. Linda Lim, a business professor at the University of Michigan, dismisses the student anti-sweatshop movement as "patronizing white-man's-burden stuff," a dismissal that bizarrely equates contemporary labor activism for sustenance wages with colonialism's massive surplus extraction from the Third World under the ideological justification of a civilizing mission. ${ }^{27}$ She also caricatures student activists' attitudes toward garment workers as "let's help these poor Third World women of color who are so victimized by us and are helpless without us,' et cetera, which is just not true and denies the benefit of these jobs to the women. These women aren't dumb, and they do have choices. The 'activists' just don't give enough credit to the women, and to their strength." ${ }^{.8}$ It is impossible to know whether Lim offered any evidence to support this assertion because her remarks are quoted in an article in Lingua Franca. But the assertion itself is absurd in the face of USAS materials and organizing practices that recognize both the gendered nature of the collusion between transnational corporations and national governments and respect garment workers as full agents in their own right.

Demonstrating a lack of familiarity with the student movement, the imperi-

26. Ann Harrison \& Jason Scorse, Moving Up or Moving Out? Anti-Sweatshop Activism and Labor Market Outcomes (Nat'l Bureau of Econ. Res., Working Paper No. 10492, May 2004), available at http://www.nber.org/papers/w10492.

27. Liza Featherstone \& Doug Henwood, Clothes Encounters: Activists and Economists Clash over Sweatshops, Lingua FrancA, Mar. 2001, at 27, available at http://www.1worldcommunication.org/ clothesencounter.htm.

28. Id. 
alist-activist metanarrative relies on two other premises: one, that students do not recognize that sweatshops provide jobs for workers in landscapes of bleak economic opportunities; and two, that they advocate boycotts of apparel manufactured in such facilities. Student activists do not advocate boycotts of factories unless the workers at those factories request one as a solution to sweatshop violations. ${ }^{29}$ Such calls rarely occur. Students emphatically reject the binary logic that presents a false choice between no jobs, on the one hand, and sweatshop employment, on the other, insisting that the real choice should be over apparel jobs that grant dignified conditions of employment for workers and pay a living wage and those that do not. USAS proposals such as the DSP seek to make stable, wellpaying jobs a reality in otherwise economically impoverished areas.

The imperialist-activist metanarrative figures students as primarily middleclass, white agents of intervention and workers as impoverished people of color, who are objects of intervention. However, as Nitsch points out, we might question this construction of student activists as a homogenous group of elite agents as overly simplistic. While the majority of the U.S. population is elite relative to the rest of the world in terms of living standards, it is important to emphasize that U.S. students constitute a racially, sexually, and economically-diverse population, though even more work needs to be done to increase this diversity. ${ }^{30}$ The United States, in comparison with other countries, has been more successful in increasing access to higher education. ${ }^{31}$ According to the 2003 census, 27 percent of the U.S. population had earned at least a bachelor's degree. ${ }^{32}$ Some of these students are non-elite in terms of their social class backgrounds and they do participate in student activism. Rather than view university students as a unified class, it might be more accurate to recognize them as crosscut by conflicting backgrounds and interests. For their part, USAS has intensified its recruitment of minority students and adopted strategies within the organization to facilitate their leadership. ${ }^{33}$ These strategies have been successful in promoting diversity in the organization. Zack Knorr, the current In-

29. United Students Against Sweatshops, About WRC Affiliation and Becoming Sweatfree, http:// www.studentsagainstsweatshops.org//index.php?option $=$ com_content $\&$ task $=$ view $\&$ id $=108$ \&Itemid $=37$ (last visited April 5, 2008).

30. Nitsch, supra note 8 , at 34-35.

31. Id.

32. U.S. Census Bureau, One in Four U.S. Residents Attends School, http://factfinder.census.gov/ jsp/saff/SAFFInfo.jsp?_pageId =tp5_education.

33. See Nitsch, supra note 8, for a description of USAS' efforts to diversify its membership and leadership. Featherstone and United Students Against Sweatshops also address the complexities of race and campus organizing in Not So Cute Any More: USAS and the Politics of Race. FeatherSTONE \& USAS, supra note 2, at 62. 
ternational Campaigns Coordinator of USAS, estimates that today "roughly one third of the organization" and "slightly more than half of [the] coordinating committee," the governing body of USAS, are people of color. ${ }^{34}$

But even if the student anti-sweatshop movement conformed to its representation by its detractors as a monolithic class and racial formation, we might ask: so what? Do the class and racial identities of particular subjects render their actions automatically suspicious or reduce the potential benefits of their activism? I would argue no. Successful social movements depend on the participation of diversely located subjects whose immediate and direct interests might not coincide with those of the group's agenda. The anti-sweatshop movement more generally is a loose network of international organizations consisting of trade unions, NGOs, and student groups. ${ }^{35}$ For a social or political force to become decisive, the movement must have a complex social composition in which the basis of its unity does not arise from the economic position of its agents so much as it emanates from the system of alliances that is forged by diverse social actors within it. ${ }^{36}$ One of the successes of the student anti-sweatshop movement in the United States is its pedagogical function to educate the public about the working conditions of the young women who stitch and sew our clothes. Former USAS member Jeremy Blasi refers to this educational mission as "commodity defetishization," the exposure of the social relationships between the consumer and the producer materialized through the tactile intimacy of our clothing. ${ }^{37}$

Aside from mainstream economists such as those affiliated with the Academic Consortium on International Trade (ACIT) and free market media pundits, the student anti-sweatshop movement has gained a substantial degree of popular support by exerting ethical authority and exercising moral leadership through its consumer education campaigns. ${ }^{38}$ As Scholars Against Sweatshop

34. Email from Zack Knorr, International Campaigns Coordinator for USAS, to Purnima Bose (Oct. 16, 2007) (on file with author).

35. Tim Connor, Time to Scale up Cooperation? Trade Unions, NGOs, and the International AntiSweatshop Movement, 14 Dev. Prac. 61, 64 (2004).

36. Stuart Hall, Gramsci's Relevance for the Study of Race and Ethnicity, in StUarT HALL: CRITIcal Dialogues In Cultural Studies, supra note 1, at 411, 425.

37. Jeremy Blasi, Threads of Protest: Commodity Defetishization and the Student Anti-Sweatshop Movement, (May 2000) (unpublished B.A./B.S. Thesis, U.Cal. Berkeley) (on file with author).

38. The ACIT formed in 2000 under the leadership of prominent economist Jagdish Bhagwati and other specialists in international trade. In the summer of 2000, the group sent unsolicited letters to university and college presidents, urging caution regarding the student anti-sweatshop movement's demands for the creation of independent monitoring institutions; they called for the involvement of trained academics in these discussions, presumably economists and business spe- 
Labor (SASL) notes, "the anti-sweatshop movement has prompted a new body of research and discussion that is deepening our understanding of the specific issues at hand." ${ }^{39}$ In this sense, USAS and academics are part of a historic bloc that also includes trade unions and NGOs and has the potential capacity to propagate an intellectual, moral, and economic collective program that can contribute to meaningful change for some garment workers.

\section{United Students Against Sweatshops: The Emergence of a National Movement}

In the mid-nineties, when the media were bemoaning the apathy of Generation X, some young people responded to organized labor's attempts to develop transnational alliances among workers. Recall that in the eighties and early nineties much of the rhetoric emanating from organized labor was protectionist, targeting foreign countries like Japan rather than multi-national capital as the source of workers' woes. This analysis of the global economy resides at the center of Michael Crichton's 1992 novel Rising Sun which represents Japanese business as the dragon that American labor must slay to regain its economic vitality. ${ }^{40}$ Under John Sweeny's leadership, the AFL-CIO began to recognize the importance of transnational labor alliances and aggressively recruited and trained college students in organizing tactics and strategies; part of these efforts entailed creating "Union Summer," which enables students to serve as interns on specific labor campaigns during their summer vacations. In 1997, student interns at the Union of Needletrades, Industrial and Textile Employees (UNITE), under Ginny Coughlin's guidance, researched the production of collegiate apparel and returned to their universities with knowledge of the industry and organizing skills. ${ }^{41}$ Tico Almeida, then an undergraduate at Duke University, organized his fellow students to successfully lobby the administration "to pass a code of conduct, requiring manufacturers of Duke apparel to maintain safe, independently monitored workplaces in

cialists like themselves who advocated free market policies. ACIT Steering Committee, Letter to American University Presidents (July 29, 2000), http://www.fordschool.umich.edu/rsie/acit/ Documents/Anti-SweatshopLetterPage.html. In October 2001, Scholars Against Sweatshop Labor (SASL) issued a convincing rejoinder to the ACIT's assertions in a statement. SASL Steering Committee, Statement (Oct. 2001), http://peri.enomaly.net/SASL-Statement.253.0.html.

39. SASL Steering Committee, supra note 38.

40. Michael Crichton, Rising Sun (1992).

41. Featherstone \& USAS, supra note 2 , at 11. 
which workers were free to organize. ${ }^{32}$ Subsequently, student-led campaigns to demand that universities adopt worker-friendly codes of conduct for their licensees emerged at a significant number of colleges and universities. Students also founded USAS in the spring of 1998 as a network of campus anti-sweatshop groups. ${ }^{43}$ Drawing on traditional forms of student protest such as sit-ins, they pioneered creative organizing strategies that included puppet shows, educational workshops, occasional clothing-optional protests, and street theater.

Around the same time, in 1996, the Clinton administration convened the Apparel Industry Partnership that founded the Fair Labor Association (FLA) three years later, which was to allay concerns about the garment industry by monitoring factories. The FLA consisted of a partnership between corporations, including Nike, Eddie Bauer, and Liz Claiborne, universities, and some NGOs. The corporate element of the organization was reflected in its factory monitoring proposal: inspections would occur infrequently, be pre-announced to factory owners, and be conducted by U.S. auditing firms instead of local NGOs. Indeed, UNITE, the AFL-CIO, the Interfaith Center on Corporate Responsibility, and the Retail, Wholesale and Department Store Union withdrew from the partnership with the FLA, citing concerns over the protection of worker-rights, a clear living-wage standard, and the absence of adequate enforcement mechanisms for violations. ${ }^{44}$

Sharing this lack of confidence in the FLA, students pushed for the creation of an alternative monitoring organization that would be independent of both corporations and the government. The Worker Rights Consortium, as they conceived it, would be composed of three constituencies: universities, independent labor rights experts, and students. (Currently, the WRC has a fifteen-member board with five seats allotted to each constituency). It would conduct factory inspections in response to complaints that it received from workers and make recommendations to universities and colleges on the basis of its fact-finding missions. It is worth stressing that the $\mathrm{WRC}$ is a reactive institution insofar as it responds to worker-initiated grievances. Unlike the characterization of workers as passive objects of intervention in the imperialist-activist metanarrative, the WRC locates agency squarely with garment workers.

42. Id. at 12 .

43. Id.

44. For a detailed analysis of the FLA's early proposal for monitoring see USAS, Colbege Clothes from the Concrete Prison: Sweatshops, Independent Monitoring and the Fair Labor Association 26-27 (July 1999). For a comparison of the FLA and WRC in their formative stages, see David Moberg, Getting Schooled: Students Are Making Manufacturers Sweat, in IN THEsE Times, Dec. 12, 1999, at 20. See also David Moberg, Bringing Down Niketown: Consumers Can Help, But Only Unions and Labor Laws Will End Sweatshops, The Nation, June 7, 1999, at 15. 
Along with the adoption of codes of conduct, students urged their universities to become members of the WRC. Early on, they recognized the movement would be a long-term struggle that would be punctuated by specific campaigns arising from particular circumstances. Students also valued the importance of legal documents and the creation of a discursive space to further workers' rights. Many codes of conduct include language requiring licensees to pay their workers a "living wage" and a call for "factory disclosure," the requirement that licensees divulge the location of their facilities. Almeida explains, "if we were to hold the manufacturers of our college merchandise accountable, we were going to have to force them to open themselves up to public scrutiny. ${ }^{245}$ When codes of conduct were being formulated, some people in the movement recognized that the "living wage" vocabulary was meaningless insofar as licensees would claim that they were paying fair wages. The operative assumption was that the presence of this language in university codes enabled organizing opportunities in the future and justified an independent monitoring organization such as the WRC. ${ }^{46}$

The importance of factory disclosure will be obvious to those concerned about corporate globalization. Laura E. Lyons has recently argued about the necessity of situating the status of "land" in globalization studies; she explains that actual territory is often precisely what is at stake for indigenous people and workers, who literally lose their place (homes and workplaces) when corporations shift production. ${ }^{47}$ The discourse of deterritorialization attached to transnational capital also makes it extremely difficult to conceptualize agency and resistant subjects. If a factory's location is a mystery, then the conditions of its workers and their attempts to organize will also be shrouded in secrecy. While recognizing the importance of factory disclosure, I was skeptical that universities and licensees would agree to its inclusion in codes of conduct because I thought they would claim that such information could be protected under trade secrets. Fortunately, I was wrong, and factory disclosure is now routine and generally available on university websites.

Those campus anti-sweatshop groups that were successful in convincing their administrations to adopt codes of conduct were shrewd in their recognition that such documents could provide the legal basis to press for more meaningful change later.

45. Featherstone \& USAS, supra note 2 , at 16.

46. The Collegiate Licensing Company or the Licensing Resource Group enforce the commercial aspects of licenses such as royalties and technical performance, while the FLA and/or the WRC investigate compliance of the labor aspects of university codes of conduct.

47. Laura E. Lyons, Dole, Hawai'i, and the Question of Land under Globalization, in Cultural History and the Global Corporation 93 (unpublished manuscript, on file with Purnima Bose \& Laura E. Lyons, Indiana University). 
The presence of language in university codes of conduct setting employment standards in wages and benefits, working hours, overtime compensation, health and safety, and women's rights; prohibiting discrimination, harassment, abuse, and forced labor; and, most importantly, recognizing the right of association and collective bargaining placed all of these areas squarely on the agenda for future campaigns to materialize the utopian labor vision embodied in these documents into a living reality. ${ }^{48}$

\section{No Sweat! in the Heartland: Student Educationals and Faculty Solidarity}

At Indiana University (IU), several students approached a few faculty members-Milton Fisk, Amber Gallup, and me-in the summer of 1999, to develop a workshop on the relationship between sweatshop labor, the global economy, and human rights abuses. They asked us to create a short (thirty-minute) and long (fiftyminute) version of the workshop that students could be trained to present to different audiences. Patterned on Miles Horton's model of popular education that was perfected at the Highlander School in Appalachia, the workshops we devised included visualization exercises to facilitate audience participation and also a section that responded to "myths of the global economy." Concluding with information specific to the IU sweat-free campaign, the presenters outlined the students' demands and collected the e-mail addresses of audience members who were interested in participating in the group. Students and their allies gave these workshops to several thousand people in the first year of the campaign, taking their presentations to classrooms, churches, community groups, and union meetings. The thirty-minute workshop, in particular, was ideal for incorporating into classes as its length allowed faculty to either build additional materials on the topic into their class session or, in the case of more reluctant faculty members, gave them sufficient time to cover their original lesson plans. Faculty members in some disciplines such as political science, history, English, apparel merchandising, sociology, international studies, and anthropology, were more amenable to scheduling anti-sweatshop presentations than those in economics or the business school. The anti-sweatshop educationals raised the profile of the campaign on campus, successfully recruiting new student members and eliciting the support of faculty across campus.

48. The WRC has a model code of conduct on its website, which it uses for the basis of its investigations; it does not, however, require institutions to adopt the same code as a condition of membership. Worker Rights Consortium, Model Code of Conduct, http://www.workersrights.org/ coc.asp (last visited April 4, 2008). 
Simultaneously in the fall of 1999 , students entered into weekly bargaining sessions with the administration to urge IU to join the WRC and to adopt a code of conduct, one that was stricter than the codes that were circulating at the time. The bargaining sessions included three constituencies: personnel representing the administration, students, and a few sympathetic faculty members. Representatives from the White River Central Labor Council, Jobs with Justice, and local unions such as the International Brotherhood of Electrical Workers periodically attended bargaining sessions as observers and to demonstrate their support for students. The university was represented by officials from the trademark and licensing department and the Office for Student Affairs, while students and faculty argued for the desirability of IU joining the WRC and adopting a stringent code of conduct. Raising legitimate questions regarding the institutional structure of the WRC and the logistics of monitoring factories, university administrators were open to the students' concerns. Unlike other institutions, the tenor of these sessions was amiable rather than confrontational in large measure because of the efforts of students to create an affective bond between university officials, students, and sweatshop workers. Arriving early for bargaining sessions, the students initiated casual and unofficial conversation with administrators, distributed carnations on one occasion, circulated Valentine's cards to sign for factory workers, and brought a cake to celebrate the university's decision to opt for factory disclosure. ${ }^{49}$ These positive interactions would result in the formation of an anti-sweatshop advisory committee. The committee has worked together constructively over the years unlike similar committees at other institutions where university officials are often at loggerheads with student activists.

Independent of the bargaining sessions, Jeffrey C. Isaac, a political scientist, drafted and circulated a faculty petition in December 1999. The petition featured a significant number of chaired professors and department heads as signatories, urging Myles Brand, then president of the university and now the head of the National Collegiate Athletic Association (NCAA), "to support a serious Code of Conduct on Sweatshop Labor." While Isaac's letter did not include any explicit references to the students' demands that IU join the WRC, it did urge IU to adopt a code of conduct that included safeguards on wages and benefits, child labor, health and safety, freedom of association and collective bargaining, harassment and abuse of workers, gender-specific violations, and the necessity for "a meaningful monitoring process" all standards endorsed strongly by both No Sweat! and the WRC. Isaac framed the faculty request by reminding Brand that the sweatshop issue is "a particularly com-

49. Micah Maidenberg, $A$ Show of Power, in Students Against Sweatshops, supra note 2, at 16. 
pelling moral issue for public universities such as Indiana University, because such universities have a democratic mission and seek to cultivate critical intellectual skills and civic responsibilities." "In "In order to be true to these values," he wrote, "we must take a stand against human rights violations wherever they occur. And when we can actually make a difference, we should seek to do so." ${ }^{\text {.1 }}$ The petition's appeal to the humanistic mission and public responsibilities of the university clearly was convincing for faculty, over 160 of whom became signatories. As Isaac's petition illustrates, faculty can provide an important supporting role for students by convincing administrators to take student requests seriously.

In February 2000, President Brand agreed to the students' demands and also convinced several other Big Ten universities, such as the University of Michigan and University of Wisconsin, to join the WRC. The WRC's membership was less than ten at the time, and IU's decision helped give the fledgling institution some momentum in its membership drive. (Currently, it has over 150 members). The President also established an advisory committee to apprise him of matters related to university-licensed apparel, composed of equal numbers of administrators and staff, faculty, and students. Significantly, the representatives of the administration on the committee are by-and-large the same individuals who participated in the bargaining sessions; their long term involvement and the stability of the committee's composition-with the exception of student representation, which experiences turnover because of graduation-has meant that the committee as a whole has a good grasp of the issues, a commitment to the ethical production of university apparel, and an institutional memory of the WRC's record. ${ }^{52}$

The Anti-Sweatshop Advisory Committee responds to reports from the WRC about violations or complaints at specific factories, discusses a course of action and makes recommendations to our current president. The committee's recommendations generally consist of a series of actions, beginning with sending a letter of concern to our licensee. We ask for information regarding allegations of abuse and ask the licensee to cooperate with the WRC in any investigations. If this initial letter generates a negative response, we send a follow up missive, reminding the licensee of contractual obligations and indicating that its contract might be jeopardized by lack

50. Letter from Jeffrey C. Isaac, Rudy Professor of Political Science, Indiana University, to Myles Brand, President, Indiana University (Dec. 1999)(on file with author).

51. Id.

52. Minutes of the IU Anti-Sweatshop Advisory Commitree meetings are available at http:// www.indiana.edu/ -wrciu/. Indeed, the IU Anti-Sweatshop Advisory Committee proactively organized a conference on fair trade in September 2005, bringing together licensing officials, academics, and student activists to debate the desirability and feasibility of fair trade proposals. 
of cooperation. In the rare instances that we break a contract with a licensee, we stress that we will consider renewing it once the corporation redresses workers' grievances. We try, above all, to avoid breaking a contract because we do not want to jeopardize the employment of workers. For this reason too, USAS often discourages boycotts of individual factories or brands as a response to labor violations unless the boycott has been requested by workers at the particular factory.

\section{Industry Volatility, Structural Impediments to Meaningful Change and the Designated Suppliers Program}

Because a number of institutions are working in tandem through the WRC, the anti-sweatshop movement has achieved some measure of success in redressing labor violations at specific factories in the Dominican Republic $(B J \& B)$, Thailand (Lian Thai), Indonesia (PT Dada and PT Kolon Langgeng), Mexico (Kukdong), and the United States (New Era). For instance, in 2001, workers at the Kukdong Factory in Mexico, now Mexmode, which produced university apparel for Nike and Reebok, complained that the national union, Confederación Revolucionaria de Obreros y Campesinos (CROC), was not representing their interests: workers were paid wages below the Mexican minimum wage and those stipulated in university codes, sometimes hit with hammers and screwdrivers by management, fed rancid food in their cafeteria, fired for engaging in union activity, and denied the right of association to form an independent union, among other violations. As a result of a WRC fact finding mission initiated by Mexican workers and university pressure, management allowed workers to organize an independent union, Sindicato Independiente de Trabajadores de la Empresa Kukdong Internacional de Mexico, SITEKIM, now SITEMEX, one of the first in Mexico. ${ }^{53}$ The new union successfully negotiated a contract that included a 10 percent wage increase, a 5 percent increase in benefits, and an attendance bonus. ${ }^{54}$

53. Worker Rights Consortium, WRC Investigation re Complaint Against Kukdong (Mexico), Preliminary Findings and Recommendations (Jan. 24, 2001), http://www.workersrights.org/ Freports/Report_Kukdong_1.pdf; WRC, WRC Investigation re Complaint Against Kukdong (Mexico), Report and Recommendations (June 20, 2001), http://www.workersrights.org/Freports/ Report_Kukdong_2.pdf.

54. Robert J. S. Ross, A Tale of Two Factories: Successful Resistance to Sweatshops and the Limits of Firefighting, 30 LAB. STUd. J. 65, 71 (Winter 2006). Unfortunately, BJ\&B has subsequently closed. Ralph Armbruster-Sandoval reaches similar conclusions to Ross regarding the importance of both worker empowerment and solidarity in the success of labor campaigns, though he does not focus on the student anti-sweatshop movement. See Ralph Armbruster-Sandoval Workers of the World 
Several years into this kind of work, it became apparent that the victories have been provisional insofar as remediation might have occurred at specific factories as a result of the WRC focusing attention on workers' struggles and universities applying pressure on their licensees only to have the brand shift production to another location several months or a few years later. As a result, those factories that have made genuine efforts to respond to labor concerns are punished. The structure of the apparel industry rather than the industry's desire to retaliate against more progressive factory owners makes long-term meaningful change almost impossible..$^{55}$ Typically, each factory produces garments for a number of brands with university-licensed apparel comprising less than 5 percent of annual production, making it difficult for universities to have much leverage over specific factories and complicating the task of monitoring facilities. Moreover, the industry is extremely volatile and unstable "with brands constantly shifting business from factory to factory in search of the cheapest price-causing frequent factory closures and a chronic lack of job security for workers." ${ }^{\text {66 }}$ Even with university-licensed goods, there is little year-to-year or even month-to-month consistency in the thousands of factories that licensees use to produce logo goods. The phase-out of the Multi Fiber Arrangement in January 2005, which imposed quotas on the quantity of textiles and garments that developing countries could export to developed ones, has exacerbated the volatility in the industry as brands have shifted their contracts to factories in China and South Asia. Particularly hard hit have been some of the Pacific Basin countries that have had to contend with the economic aftermath of the devastating tsunami they experienced at around the same time.

Recognizing the structural constraints that the volatility of the apparel industry places on worker empowerment, USAS devised in the fall of 2005 a Designated Suppliers Program (DSP). The program calls for universities to source their apparel from designated supplier factories that "have been determined by universities to have affirmatively demonstrated full and consistent respect for the rights of their employees. ${ }^{.57}$ In addition to adhering to standards embodied in university

Unite? The Contemporary Anti-Sweatshop Movement and the Struggle for Social Justice in the Americas, 32 Work \& Occupations 464 (Nov. 2005).

55. Scott Nova, Executive Director's Memo to Universities (Oct. 11, 2005), http://www.work ersrights.org/DSP/WRCExecMemo_10-11-05.doc.

56. United Students Against Sweatshops, The Sweat-Free Campus Campaign Frequently Asked Questions (FAQ) for the University Community 4 (Fall 2005), http://www.studentsagainstsweat shops.org/docs/NEWSweatFreePacket.pdf.

57. United Students Against Sweatshops, Designated Suppliers Program 1 (Sep. 2005), http:// www.studentsagainstsweatshops.org/docs/designatedsuppliers.doc. 
codes of conduct, factories will also have to evidence a respect for rights of association and pay a living wage. The USAS DSP further stipulates that university licensees will pay these factories prices for their products sufficient to allow factories to achieve these standards. Prices will represent modest increases over industry norms, and licensees will be expected to maintain the kind of long-term relationships with these factories necessary to allow for a reasonable degree of financial stability and job security. These factories will produce primarily or exclusively for the university logo goods market..$^{58}$

Phased in over three years, implementation in the first year would require universities to source 25 percent of their licensed apparel from designated supplier factories. In the second year, this percentage increases to 50 percent, and in the third-year 75 percent of licensed apparel would be sourced from these facilities. After the 75 percent level is reached, universities would evaluate the effectiveness of the program and "the desirability of applying the system to $100 \%$ of university production," recognizing "that there may be value in some university production occurring outside of the sphere of the Designated Suppliers Program in order to maintain a broader influence on the apparel industry at large." 59

The DSP has subsequently been modified by a DSP Working Group, consisting of representatives of the thirty-six universities that have signed on to the proposal as of August 1,2007, as well as representatives of USAS. While the language regarding 100 percent sourcing from designated factories following the phase-in period has been eliminated, the revised proposal still contains strong requirements for living wages and guarantees for freedom of association. It asks licensees to meet four major obligations: sourcing requirements from designated factories of 25 percent, 50 percent, and 75 percent over three years; fair price standards to enable designated factories to pay a living wage; majority collegiate production requirement to enable universities to have leverage over factories; and long-term production agreements (no less than three years) that "commit the licensee to a minimum volume of orders each year." ${ }^{\circ 0}$

In the interests of transparency, the DSP Working Group allows university observers and FLA officials to attend its meetings and even sets aside time for their comments. ${ }^{61}$ While the group's commitment to transparency is commend-

58. Id.

59. Id.

60. DSP Working Group, The Designated Suppliers Program-Revised 3 (Sept. 2006), http:// www.workersrights.org/DSP/Designated\%20Suppliers\%20Program\%20-\%20Revised.pdf.

61. The FLA issued a statement expressing considerable reservations on possible anti-trust violations, the selection of factories, arbitration, the calculation of a living wage, the program's eco- 
able, some of the observers seem hostile to workers rights and can sometimes obstruct the implementation of projects. At the June 2007 DSP Working Group meeting, for instance, one observer proposed modifying the majority production requirement. Yet when pressed by university representatives from other institutions on whether the change in wording he desired would secure the participation of his institution in the DSP, he remained noncommittal.

\section{Definitional Difficulties: the DSP, "Freedom of Association," AND THE "Living WAGE"}

The wording of the DSP Working Group's draft takes into account that the climate for labor organizing is widely diverse around the world and is carefully crafted to allow for flexibility and local contexts. "Freedom of association" figures prominently in the proposal but is defined fluidly to adapt to local circumstances; the document stipulates that a factory's participation in the program is contingent on "demonstrable respect for the right to organize and bargain collectively, as evidenced by the presence of a legitimate trade union (or other representative employee body) and/or proactive steps by management necessary to ensure that workers can freely exercise these rights without fear of retaliation." ${ }^{\prime 2}$

The DSP elaborates on the steps necessary to produce a climate that is conducive for labor, specifying that factories communicate their "openness to workers' exercise of their associational rights," refrain from punitive action against workers for exercising these rights and for engaging in bargaining, and "recognize and commence good faith negotiations with any duly constituted worker body" in a timely manner. ${ }^{63}$ "Other representative employee body" and "duly constituted

nomic viability, and potential cost increases for consumers. FLA, Issues and Comments on the Proposal (Feb. 16, 2006), http://www.workersrights.org/dsp.asp (follow link under "Statements/ Documents from Organizations Involved in the DSP Debate" heading). Auret van Heerden, president and CEO of the FLA, believes that ensuring compliance with codes of conduct would be better served by asking factories to have managers trained in worker rights. "Just about every factory I visit doesn't have an HR official in charge of hiring. Somcone isn't trained, so they ask people about trade union affiliation or pregnancy status or something else inappropriate," he observes. Scott Jaschik, Codes Don't Work. Inside Higher Ev, Sept. 28, 2006, http://www.insidehighered .com/news $/ 2006 / 09 / 28 /$ wrc. While the goal of having managers trained in labor rights is laudable, it is not clear how their presence would address concerns about starvation wages or the instability of the industry as a whole, the foci of the DSP. Scott Nova, the executive director of the WRC, offers a detailed response to the FLA's concerns in his March 4, 2006 letter to van Heerden (Mar. 4, 2006), http://www.workersrights.org/DSP/WRC_Letter_to_FLA_3-4-06.pdf.

62. DSP Working Group, supra note 60 , at 8.

63. Id. 
worker body" can substitute for trade unions, and these definitions demonstrate the recognition that not all countries (China, for example) permit workers to unionize. The document defines a "representative employee body" as "an organization that was established without management interference, that democratically elects its leaders, and that is able to carry out the essential functions of a union, including collective bargaining." ${ }^{\prime 64}$ The DSP also emphasizes the necessity of enabling access to factories by "labor rights experts, representatives of NGOs and trade unions to conduct worker rights education, overseen by the WRC." 65

Many university codes of conduct include language about the desirability of a living wage, and it is the presence of this language that has enabled students to focus attention on the issue through the DSP. USAS defines a "living wage" as a “'take home' or 'net' wage, earned during a country's legal maximum work week, but not more than 48 hours, that provides for the basic needs (housing, energy, nutrition, clothing, health care, education, potable water, childcare, transportation and savings) of workers and their families." 66 Critics of the living wage have pointed to economic discrepancies between countries, suggesting that it is a relative term and basic requirements in one country might be luxuries in another. This criticism is founded on the incorrect assumption that students want to impose a universal living wage that is fixed across countries. On the contrary, the DSP will calculate different living wages for countries in which universities source their apparel. Of the technical aspects of performing these calculations, which licensees complain are "too complex and too thorny" to untangle, USAS wryly comments, "this is an ironic position to be taken by multinational companies that have developed cutting edge supply networks for manufacturing clothing in the farthest corners of the globe." ${ }^{\prime 7}$

The Working Group draft of the DSP mandates that participating factories must pay their employees a living wage and defines the general method that will be used to calculate this wage in different countries, which will be determined by local experts chosen by the WRC: "These experts construct a culturally appropriate market basket of goods and services, for each country or region, sufficient to support a family of average size, and then determine the price for each of these goods and services in local markets." ${ }^{.8}$ On its website, the WRC furnishes sample

64. Id. at 2.

65. Id. at 8 .

66. United Students Against Sweatshops, The New Sweat-Free Campus Campaign 3 (2005), http://www.studentsagainstsweatshops.org/docs/NEWSweatFreePacket.pdf.

67. Id. at 22.

68. DSP Working Group, supra note 60 , at 7. 
living wages for Indonesia and El Salvador that are calculated based on this culturally specific market basket approach. Using standards developed by such bodies as the United Nations Food and Agricultural Organization and in consultation with individuals and organizations that have local expertise, the estimates are calculated to support three people (the worker and two dependents) and to provide for nutrition (averaging 2,200 calories per day), housing, energy, clothing, healthcare, education, potable water, child care, transportation, and a modest amount for discretionary spending. ${ }^{69}$

The WRC is also exploring methods for calculating living wages using purchasing power parity (PPP) conversion, an economic technique often used by international financial institutions to compare the costs of goods between countries. The PPP measures the local purchasing power of a given country's currency relative to other countries' currencies for the same goods and services. Drawing on the U.S. Department of Commerce's 2006 determination of the "extreme poverty line," half of the poverty line and about ten thousand dollars for a family of four, the WRC has used PPP conversion to generate wage figures for apparel producing countries that are roughly equivalent to those figures generated by the market basket method. The objections to the living wage requirement by the DSP's critics seem indefensible from an ethical perspective when these wages would only be sufficient to meet the local equivalent of the "extreme poverty line." Should a PPP conversion approach be adopted as the method to calculate DSP wages, the term "living wage" will not be an accurate description of what amounts to an extreme poverty wage. At the same time, there is value to retaining the vocabulary of the living wage in the DSP document for future campaigns that can galvanize around the discrepancy between the discursive construction of a living wage and the actuality of extreme poverty wages.

Labor costs constitute a very small percentage of the retail price of a garment, typically only $1-3$ percent. ${ }^{70}$ In most cases, the payment of a living wage would mean doubling or tripling labor costs from around eighteen to twenty-five cents per garment to about sixty to seventy-five cents, a negligible increase in the entire garment. ${ }^{71}$ USAS recommends that the additional labor costs be absorbed by the

69. Worker Rights Consortium, Sample Living Wage Estimates: Indonesia and El Salvador (2007), http://www.workersrights.org/LivingWageEstimates.pdf.

70. Worker Rights Consortium, The Impact of Substantial Labor Cost Increases on Apparel Retail Prices (2007), http://www.workersrights.org/Labor_Cost_Increases_and_Apparel _Retail_Prices.pdf

71. Id. 
brand, but even if the corporation refused, U.S. consumers probably would not object to this modest increase in cost, as at least one study confirms. ${ }^{72}$

\section{The DSP and Anti-Trust Law}

Critics argue that the DSP is a classic price-fixing agreement and violates antitrust laws. However, the WRC's legal counsel, Donald Baker, a former assistant attorney general in the Justice Department's antitrust division and a partner at Baker \& Miller, concludes that the program "is consistent with the Sherman Antitrust Act."73 Baker bases his assessment on "the competitive relationships and realities" of the university apparel industry. He notes that universities do not compete in the licensing function because each offers differentiated rights to licensees; they are not motivated by profit-maximizing desire so much as humanitarian impulses to respond to their students' concerns; and they are not likely to profit economically from the DSP. ${ }^{74}$ Moreover, the licensees contract for highly differentiated products that are intended for different university communities and constitute different market segments. ${ }^{75}$ While the licensees compete to produce a University's licensed products, they have not participated in the creation of the DSP. ${ }^{76}$ Baker also points out that "U.S. garment unions and manufacturers-which might well have an economic interest in Licensees having to pay higher prices for the Products—are not directly part of the Program."”7

In January 2007, the WRC asked for a Business Review Letter on the DSP from the Department of Justice (DOJ). The DOJ's Business Review process consists of an analysis of the proposal based on its legal merits by career attorneys; however, the final ruling is made by a politically appointed staff. In January 2008, the DOJ informed the WRC that it would not be able to issue a favorable Business Review Letter for the DSP. The WRC subsequently withdrew its request. It is entitled to re-submit another business review request of the DSP in the future with or without

72. John Miller, Nike to the Rescue? Africa Needs Better Jobs, Not Sweatshops, Dollars \& Sense (Sept./Oct. 2006), http://www.dollarsandsense.org/archives/2006/0906miller.html.

73. Audrey Williams June, 8 Colleges Sign On to Anti-Sweatshop Plan but Worry Over Antitrust Issues, Chron. of Higher Educ. (Mar. 27 2006), http://chronicle.com/cgi-bin/printable .cgi ?article $=$ http://chronicle.com.

74. Donald Baker, Business Review Letter Request (Jan. 12, 2006), http://www.workersrights .org/DSP/WRC\%20Business\%20Review\%20Letter\%20Request\%201-12-07.pdf.

75. Id.

76. Id.

77. Id. 
revisions to the program. Given the Justice Department's more favorable response to these issues in the past, there is reason to believe that a future administration will be better disposed to the program. Pending a different administration, an issuance of a Business Review Letter would quiet concerns that the DSP conflicts with antitrust laws and offer reassurance that the government does not intend to take any action in relation to the proposal. Such reassurance might make it easier for USAS to convince additional universities to join the program.

\section{Conclusion}

Student anti-sweatshop activism, while modest in terms of its impact on the overall apparel industry, does have enormous benefits for workers and for students. For some garment workers, the benefits have meant a material improvement in their living conditions. The implementation of the DSP could help make employment stability and wage increases a longer-lasting reality. For students, participation in the movement fosters a consciousness of international relations while giving them a sense of agency. Recognizing their connections to apparel workers in other parts of the world and the moral claims that such links entail, students are enacting a form of progressive cosmopolitan citizenship. In the wake of 9/11, signs of international consciousness among North American students seem particularly heartening.

Campus labor activism exists in a symbiotic relationship with students' academic work. No Sweat! has a diverse student membership in terms of disciplinary backgrounds, including both undergraduate and graduate students. The trajectories between theory and practice for these students vary: a number of history, English, and cultural studies graduate students come to activism as a result of their reading, while at the undergraduate level, students gravitate to majors based on their activist work, often acquiring degrees in economics, political science, and area studies. Phil Shelton, an undergraduate member of No Sweat!, describes his academic itinerary in relationship to social justice: "I started to focus my studies on issues that would pertain to the advancement of my knowledge in areas of social justice. As a dual major in International Studies and Political Science, I started to see the courses being offered to me in two groups: one group would further refine my budding idea of social justice and one that would waste my time. ${ }^{.78}$ Shelton eventually exchanged the political science major for Latin American studies because he felt "suffocated by

78. Email from Phil Shelton, Member, No Sweat! to Purnima Bose (March 27, 2006) (on file with author). 
the structure" of the political science degree and its assumption that "righteousness of [our] political system was the basis for its study." ${ }^{\text {"79 }}$ Several graduate students, who are or were members of No Sweat!, are working on interdisciplinary dissertation projects that involve the relationship between social movements, labor, representation, and globalization; their organizing experience informs the kinds of questions they pursue, resulting in innovative research in their fields. ${ }^{80}$

In addition, anti-sweatshop activism has served as a catalyst for other labor struggles as evident by the involvement of No Sweat! members with human rights campaigns against Coca-Cola; the Bloomington living wage campaign; as well as the movement to oppose the university's attempts to outsource its bookstore, motor pool, and food services; and solidarity actions with tomato pickers for Taco Bell, among other campaigns. In the midst of No Sweat!'s campaign to join the WRC, students came to know that workers at the local GE plant, a major employer in Bloomington, Indiana, had received notice of potential layoffs. No Sweat! mobilized students and a few faculty to walk the picket with GE workers, and produced a strike support manual for students and workers in their newsletter, The Sweatshop ${ }^{81}$ Former No Sweat! activist Megan Hise, who accepted a job as a labor organizer following graduation, explains how the knowledge of sweatshops gained through activism increased her sensitivity to labor issues in the United States:

In some ways it is easier to agitate a person new to these issues by initiating the dialogue with the visceral reality of the iconic sweatshop: the heat, the fatigue, the toxic odors, the hunger, the humiliation. Starting from the vantage point where the conditions are so ugly that organizing a union can mean a life or death struggle, labor solidarity suddenly seems more urgent. From there we can begin to educate people about the system that generates these abuses and draw connections to the daily struggles faced by workers in the United States. Anti-sweatshop activism, supporting textile workers of the global South, introduced me to my own labor movement, and made it relevant to me. ${ }^{82}$

79. Id.

80. Ursula McTaggart, Radicalism in America's Industrial Jungle: Metaphors of the Primitive and the Industrial in Activist Texts (unpublished dissertation, Indiana University-Bloomington) (on file with author); Nitsch, supra note 8.

81. Interview with Megan Hise, Former Member of No Sweat!, Indiana University, in Bloomington, Ind. (Aug. 6, 2007).

82. Id. 
Finally, some of our other student activists have become labor organizers after graduation as well, assuming full time positions with the AFL-CIO and the WRC. Contrary to representations of anti-sweatshop student activists as naïve, the DSP demonstrates that they have a sophisticated understanding of the global economy, labor rights, and institutionalizing meaningful change. 